\title{
The Relationship Between Motivation With Self Efficacy In Patients Who Perform Diabetic Foot Care At Diabetic Foot Polyclinic Of Ulin Hospital Banjarmasin
}

\author{
Rifa'atul Mahmudah', Angga Irawan ${ }^{2}$, Erwin Setiawan ${ }^{3}$ \\ \{rivaayoenani@gmail.com, angga_irawan10@yahoo.co.id, erwinsetiawan557@gmail.com\} \\ ${ }^{[1,2]}$ Department of Sciences in Nursing, Universitas Sari Mulia, Banjarmasin, Indonesia \\ *Correspondence: rivaayoenani@gmail.com
}

\begin{abstract}
The research aims to analyze the relation of motivation with self efficacy in patients who perform diabetic foot care at Diabetic Foot Polyclinic of Ulin Hospital Banjarmasin. The study used cross sectional design. Taked sampling by accidental sampling technique. As many sample 63 persons performing diabetic care at Diabetic Foot Polyclinic of Ulin Hospital Banjarmasin. Data were analyzed using Kendall Tau Test with $90 \%$ confidence level. The results of this study indicate a relation of motivation with self efficacy in patients who perform diabetic foot ulcers with $\mathrm{p}=0.000<\alpha=0.1$ and moderate $(\mathrm{r}=355)$, which means positive direction. There is a relationship of motivation with self efficacy in patients who perform diabetic foot care at Diabetic Foot Polyclinic of Ulin Hospital Banjarmasin.
\end{abstract}

Keywords: Diabetic Foot Ulcer, Diabetes Mellitus, Motivation, Self Efficacy

\section{Introduction}

Diabetes mellitus is a chronic disease that is still a problem in the world of health to date. According to the World Health Organization (WHO), the number of diabetics has increased from 171 million people in 2000 to 366 million in the year 2030. According to Riskesdas (2013) indicating the number of prevalence of diabetics with diabetes mellitus at $1.1 \%$ in 2007 to $1.5 \%$ in 2013 , this means an increase of diabetics mellitus as much as $0.4 \%$. In South Kalimantan Province in 2013 the prevalence of people with diabetes mellitus 269,158 (1.4\%) and latest data from 2017 obtained by diabetes mellitus sufferer who has complications of diabetic foot ulcer in the hospital in Banjarmasin for 4,446 patients.

World Diabetes Foundation (WDF) is a privately held institution of the world that is dedicated in the prevention and treatment of Diabetes mellitus in developing countries. The implementation of the World Diabetes Foundation program has proven its success, but the implementation of the program still poses obstacles from internal and external factors such as age, level of education, self-motivation, long suffering from Diabetes disease Melitus, self efficacy and family support patients to conduct self-care designed to control psychological symptoms as well as complications (health profile of Indonesia, 2015). 
Frequent complications in diabetics include diabetic foot ulcers where these complications require long treatment to overcome. Prolonged treatment can lead to psychological problems such as frustration, anxiety and depression. This psychological problem affects the patient's motivation to do wound care. Social Cognitive Theory is a theory that can increase motivation and self efficacy. So motivation and self efficacy are factors that can trigger the behavior of wound care better (Alwisol. 2016).

Research conducted by Shigaki et al., (2010) on motivation and self management of diabetes shows the results that individuals who have high motivation will have a good selfcare frequency especially for diet and examination levels Blood sugar. The research recommends the need for support from all parties to always motivate patients to improve selfcare management.

In another study mentioned that type 2 diabetes mellitus patients who have high self efficacy will be more optimal in their disease management such as diet, physical exercise, blood sugar monitoring, and foot care. It becomes very important because with good management, then further complications can be avoided. Self-efficacy also relates to motivation, where this motivation affects the self efficacy patients. Motivation and selfefficacy are also required for diabetes mellitus patients to increase self-reliance in managing diseases (Purwanti, 2013).

The results of the discussion conducted on 10 respondents consisting of 7 males and 3 women over 40 years of age obtained 5 respondents had a good self-motivation in the treatment of diabetic foot injuries and 5 respondents said less Motivated because of age-aging influence that only need home care such as changing the wound and family that majority work is also influential in motivation because there is no or rare family can Drove to the hospital for treatment of diabetic foot injuries, while the belief in healing of the wounds of 4 respondents convinced that the wound could be healed and the other 6 respondents said their wounds were difficult to cure because the average Already suffering from leg ulcer with a long time more than 1 year and have not recovered just reduce so that no further complications occur.

The purpose of this research is to know the motivation relationship with self efficacy in patients who do diabetic foot ulcer treatment in diabetic foot clinic of RSUD Ulin Banjarmasin.

\section{Methods}

Quantitative research plan with cross sectional approach. Respondents in this study amounted to 63 people chosen with accidental sampling technique in diabetic foot clinic RSUD Ulin Banjarmasin. The criteria for inclusion in this study were: Patients with diabetes mellitus, having complications of diabetic foot ulcers, aged 20-70, willing and willing to participate in research and cooperatives.

The instrument of research used is motivation questionnaire and self efficacy previously conducted validity test in the Dr. H. Moch Ansari Saleh Banjarmasin Hospital and has been declared valid. Analysis uses Kendall tau test to find out how much motivation relationship with self efficacy.

\section{Results}


Analysis of motivation relationship with self efficacy in patients who do diabetic foot ulcer treatment in diabetic foot clinic of RSUD Ulin Banjarmasin can be seen in the following table:

Table 4.6 The Relationship Between Motivation With Self Efficacy In Patients Who Perform Diabetic Foot Care At Diabetic Foot Polyclinic Of Ulin Hospital Banjarmasin

\begin{tabular}{ccccc}
\hline & Motivation & & \multicolumn{2}{c}{ Self Efficacy } \\
\hline & $\mathrm{n}$ & $\%$ & $\mathrm{~N}$ & $\%$ \\
\hline High & 61 & 96,8 & 62 & 98,4 \\
\hline Low & 2 & 3,2 & 1 & 1,6 \\
\hline Total & 63 & 100 & 63 & 100 \\
\hline$p=0,000$ & & $\mathrm{r}=355$ & & \\
& & & & \\
& & &
\end{tabular}

The above table shows that the motivation of diabetes mellitus patients with complications of diabetic foot ulcer in the treatment of injuries that have a high motivation of $61(96.8 \%)$ Patients and who have a low motivation of $2(3.2 \%)$ Patients as well as self efficacy diabetes mellitus patients with complications of diabetic foot ulcer in performing wound care that has a high motivation of 62 (98.4\%) Patients and who have a low motivation of $1(1.6 \%)$ Patients.

Based on the statistical results of the motivation variable relationship with self efficacy in diabetes mellitus patients with complications of diabetic leg injuries doing wound care using correlation test of Kendall Tau obtained $p=0,000$ and $\alpha$ value $=0.1$ with a $10 \%$ degree of error. Therefore, the value $\mathrm{P}$ (probability) is less than $0.1(\mathrm{P}<0.1)$, then it can be concluded that the motivational relationship with self efficacy patients who do wound care is meaningful. The value $\mathrm{R}=355$ which means that the positive direction and the medium relationship level.

The positive direction indicates that more and more people who have high motivation in the treatment of diabetic foot injuries, the higher also self efficacy the patient.

\section{Discussion}

1. The motivation of diabetes mellitus patients who do wound care in diabetic foot clinic RSUD Ulin Banjarmasin

Based on the results of the analysis on this study, it can be known that the motivation in diabetic patients who do diabetic foot ulcer treatment in diabetic foot clinic of RSUD Ulin Banjarmasin has been largely motivated as much as 61 (96.8\%) People. This proves that Maslow's theories say that the most basic human needs of physiological needs in a health sense are the most fundamental things that must be fulfilled before other needs arise.

The motivation classification as stated by Hamzah (2014) internal and external motivation in diabetes mellitus patients with diabetic foot ulcers is the urge to make common behavioral 
changes including intrinsic indicators and Extrinsic. Intrinsic indicators include desire, desire, encouragement, needs, expectations and ideals. Whereas, extrinsic indicators consist of selfobservation, through suggestions and recommendations, encouragement from others.

High motivation is formed because there is a motivation that comes from inside such as desire, desire, encouragement, the need to do activities, hopes and ideals. With a desire and a desire to do diabetic foot wound care and desire to heal, the patient will be encouraged to have a high motivation and can be seen from one of the questionnaires that many patients believe that the wound The diabetic foot can be cured which makes the motivating factor in the patient. The motivation that comes from external or outside includes family support, society, health workers are also the predisposition factor of the patient in the treatment of diabetic foot injuries.

The motivation itself is something that encourages, or motivating someone to behave to achieve a certain purpose (SAAM and Wahyuni, 2012).

The research of Saam and Wahyuni (2012) says the motivation to be closely related to the diet that the patient has diebatch mellitus. Patients with high motivation will regularly follow the diet because they want to heal and the routine consult the health workforce to get a proper diet pattern. Rather the low motivation is due to patients who do not pay attention to his health, about finding out the right kind of food for him. So that the motivation does not drift into effect in patients with diabetes mellitus with complications of diabetic foot ulcers that do wound care, but also affect patients with diabetic mellitus who are undergoing a diet.

Different results are shown in the low motivation as much as $2(3.2 \%)$ People. Although not particularly significant but this suggests that diabetes mellitus patients who perform diabetic foot injuries treatment are less motivated from the inside or outside as they are less encouraged to do wound care such as factors Economic and health conditions are lacking in favor.

2. Self Efficacy diabetes mellitus patients who do wound care in diabetic foot polyclinics RSUD Ulin Banjarmasin

Based on the results of the analysis on this study, it can be known that self efficacy in diabetic patients who do diabetic foot ulcer treatment in Diabetic foot clinic RSUD Ulin Banjarmasin mostly have a high self efficacy as much as $62(98.4 \%)$ People and only 1 (1.6\%) People who have self efficacy low. There are several factors that affect self-efficacy, among others, age, education level, family support and long suffering from diabetes mellitus.

Research by Albikawi and Abuadas (2015) stated that young diabetic patients often do foot care compared to elderly patients. This is because elderly patients have other chronic diseases and have been exposed to complications of diabetes mellitus that will inhibit their self-treatment. Furthermore, the level of education usually affects the ability to process information. Patients with higher levels of education are reported to have self efficacy and good self-care behaviors. Ngurah (2014) said diabetics who have higher education are easier to access information about their illness and treatment to prevent further complications that can be caused by diabetes mellitus type 2 such as diabetic foot ulcer. This happens because they are more mature towards changes in him so that it is more easily received positive influences from the outside including health information (Ngurah \& Sukmayanti, 2014). Good knowledge is also the key to the success of diabetes mellitus management with complications of diabetic foot ulcers.

The next factor is family support, the results of Wantiyah's research (2010) found that there is a link between social or family support with self efficacy. Likewise, from the research of Pertiwi (2015) which shows that the support of couples contributes to the 
adherence to the treatment of diabetes mellitus. In the research of Ariani (2011) concluded that respondents who received good family support have a chance of 5 times to show a good self efficacy compared with a reponden that lacks family support.

The latter factor is long suffering from diabetes mellitus respondents in this study have had an average long time suffering from diabetes mellitus for 9 years. Along with the duration of the illness, patients can learn how to manage the illness (Ngurah \& Sukmayanti, 2014). Research Wu et al., (2006 in Ariani 2011) found that patients who have suffered from diabetes mellitus $\geq 11$ years have good self-efficacy than patients who suffer from diabetes mellitus $<10$ years. This is because patients have experienced managing their illness and have a good koping. While according to Ngurah (2014) found that patients suffering from diabetes mellitus type $2>5$ years have a good self efficacy. As well as respondents who have received a chance to do foot care 2 times better. Compared to those who have never received counseling (Diani, 2013).

3. Motivation relationship with Self Efficacy in patients who perform diabetic foot ulcer treatment

According to the table 4.6 can be concluded there is a link between motivation with self efficacy in patients who do diabetic foot ulcer treatment with a value of $P=0,000, r=$ 355 , with moderate correlation strength and positive correlation direction. Based on these results it can be concluded that the higher the motivation to eat higher also self efficacy patients in conducting diabetic foot ulcer treatment.

Motivation is defined as the encouragement found in one's self to try to make a better behavior change in fulfilling his needs (Hamzah, 2014). The success of diabetes mellitus management depends on the motivation and awareness of the patient itself to conduct selfcare management. The study was also reinforced by previous research conducted by Shigaki, et al (2010), that high motivation individuals will have a good frequency of self-care. Motivation is one of the factors that influence the patient's self-efficacy. High motivation can improve diabetes mellitus patients ' self-efficacy.

According to Social Cognitive Theory, human motivation is regulated from previous experience and is influenced by 3 self-stimulating motivators for an assortment of objectives and aspirations, namely attributes, expectations and objectives. The first attribute, how individuals interpret their successes and failures. Secondly, motivation is a function of individual expectations and behavioral patterns that will result in the outcome as expected. Third, is the goal, to get the motivation effect, the individual must have a purpose and various changes on some standards so that they can evaluate themselves (Jamdafrizal, 2006).

Highly motivated individuals will be seen in their actions or behavior. Individuals will have a good belief that he or she is able to perform a certain task or action. Individuals who behave based on intrinsic motivation will be more enduring and continuously motivated than individuals who behave due to extrinsic motivation. Therefore healthcare professionals should provide a clear health education to increase patient self-awareness as well as increase the intrinsic motivation of the patient so that the patient has a conviction of his ability to do the right self-treatment of self-care for their own consciousness or without the compulsion of others (Purwanti, 2014).

In the table 4.6 it appears that $62(98.4 \%)$ Respondents have a high self efficacy in the treatment of diabetic foot ulcers. Self-Efficacy is an individual belief about its ability to motivate oneself, cognitive resources, and the actions needed to successfully perform certain tasks in a particular context (Ngurah \& Sukmayanti, 2014). According to Alwisol, 2016 selfefficacy source is behavioral change, in the key Bandura system is a change in expectations 
self efficacy. Self efficacy or belief in self-habit can be acquired, altered, enhanced or lowered, through one or a combination of four sources, namely experience the mastering of a feat, vicariius experience, social persuasion, and emotional generation. Increased self-efficacy can improve adherence to recommendations for treatment of the regimen on chronic diseases (Mishali et al., 2011).

Self-efficacy in people with diabetes mellitus will encourage patients to maintain the necessary behaviors in patients ' personal care such as diet, medication, and other diabetes mellitus treatments (Ngurah \& Sukmayanti, 2014). Type 2 diabetes patients who have high self efficacy will be more optimal in their management such as diet, physical exercise, blood sugar monitoring, and foot care. It becomes very important because with good management, then further complications can be avoided. Self efficacy also relates to motivation, where this motivation affects the self efficacy patients. Motivation and self efficacy are also needed for diabetes mellitus patients to increase self-reliance in managing diseases (Purwanti, 2014). Self efficacy plays an important role in the process of behavioral change, as self efficacy can stimulate motivation to health behavior through the expectations of its belief (Mohebi et al., 2013).

So, it can be concluded that there is a link between motivation and self efficacy against diabetic foot ulcer care behaviour. Foot care behaviour is a component of self care in diabetes mellitus patients. This is because diabetes mellitus patients who have self efficacy both will be motivated and encouraged to maintain their health by doing diabetes mellitus management, including diabetic foot ulcer treatment.

\section{Conclusion}

Based on the results of the explanation and research discussion, can be concluded:

1. Diabetes mellitus patients with complications of diabetic foot ulcer with high motivation of $61(96.8 \%)$ People and who have low motivation as much as $2(3.2 \%)$ People.

2. Diabetes mellitus patients with complications of diabetic foot ulcers that have a self efficacy high as much as $62(98.4 \%)$ People and who have low motivation as much as 1 (1.6\%) People.

3. There is a relationship between motivation and self efficacy patients in the treatment of diabetic foot ulcer in the diabetic foot polyclinic RSUD Ulin Banjarmasin with the value $\mathrm{P}=0,000$ and the medium relationship $(\mathrm{R}=355)$. 


\section{References}

[1]. Albikawi, Z.F. and Abuadas, M. Diabetes Self Care Management Behaviors Among Jordanian Type Two Diabetes Patients. American International Journal of Contemporary Research. (2015).

[2]. Alwisol. Psikologi Kepribadian. Universitas Muhammadiyah Malang: Malang. (2016).

[3]. Ariani, Yesi. Hubungan antara motivasi dengan efikasi diri pasien DM tipe 2 dalam konteks asuhan keperawatan di RSUP H. Adam Malik Medan [tesis].Depok : Fakultas Ilmu Keperawatan Universitas Indonesia. (2011).

[4]. Diani. 2013. Pengetahuan klien tentang diabetes melitus tipe 2 berpengaruh terhadap kemampuan klien merawat kaki. Jurnal Keperawatan Indonesia, Volume 16 No.2. (2013).

[5]. Hamzah. Teori Motivasi dan Pengukurannya.Jakarta:Bumi Aksara. (2014).

[6]. Jamdafrizal. Exploring the motivation of [internet] learning. [Downloaded on August 23, 2017]. Available on http://www.scribd.com/doc/. (2006).

[7]. Mishali, et al. The Important of Measuring Self-Efficacy in Patient With Diabetes. Family Practice. (2011).

[8]. Mohebi S., et all. Review The Key Role Of Self-Efficacy In Diabetes Care. Journal of Education and Health Promotion. (2013).

[9]. Ngurah, I \& Sukmayanti, M. Self-efficacy in Diabetes mellitus type 2. Department of Nursing. Denpasar Health Polytechnic. (2014).

[10]. Health profile of Indonesia. Ministry of Health Republic of Indonesia. (2015).

[11]. Riskesdas. Basic health Research. Jakarta: Health Research and Development Agency Health Ministry RI. (2013).

[12]. Pertiwi, Intan. Pair support relationship and self-efficacy by treatment of Diabetes Mellitus type 11 [thesis]. Muhammadiyah University of Surakarta. (2015).

[13]. Purwanti, Lina Ema. Motivation relationship with the self-efficacy of type 2 DM patients in performing foot care in the working area of North Ponorogo Puskesmas. Gaster Volume 11 No 2. (2014).

[14]. Saam and Wahyuni. Nursing Psychology. Jakarta: PT Raja Grafindo Persada. (2012).

[15]. Shigaki, et all. Motivation and Diabetes self-management (abstract). [Downloaded on date 9 January 2018]. Available on: I http://www.ncbi.nlm.nih.gov/pubmed/20675362. (2010).

[16]. Wantiyah, Sitorus, R., Gayatri, D. Factors affecting the patient's self-efficacy of coronary heart disease in the context of nursing care at RSD Dr. Soebandi Jember [thesis]. Bogor: UI. (2010). 